\title{
Attitude of University Students towards the Leisure Noise Induced Tinnitus and Hearing Loss
}

\section{Shumaila Malik ${ }^{1}$, Sumera Nawaz Malik², Fazaila Ehsan³ ${ }^{3}$ Waqas Azeem ${ }^{4}$}

${ }^{1}$ Audiologist, Children Hospital, Faisalabad.

${ }^{2}$ CCC-SLP, Mission Point in Flint, Michigan.

${ }^{3}$ Consultant SLP - Bahria International Hospital - Lahore

${ }^{4}$ Senior Special Education Teacher Hearing Impaired Children Government Special Education Centre (secondary),

Samundri Faisalabad

$\frac{\text { Author's Contribution }}{{ }^{1-2} \text { Conception and design, Collection }}$ and assembly of data, ${ }^{2}$ Analysis and interpretation of the data, ${ }^{3} \mathrm{Critical}$ revision of the article for important intellectual content, Statistical expertise 1-4Final approval and guarantor of the article

Article Info.

Received: Dec 31, 2020

Acceptance: Nov 29, 2021

Conflict of Interest: None

Funding Sources: None

Address of Correspondence Fazaila Ehsan

Email Id: fazailaa.ehsaan@gmail.com

ORIC Id: 0000-0003-1380-1547

Cite this article as: Malik S, Malik SN, Ehsan F, Azeem W. Attitude of University Students towards the Leisure Noise Induced Tinnitus and Hearing Loss. JRCRS. 2021; 9(2):5358.

DOI: $10.53389 / J R C R S .2021090203$

\section{A B S T R A C T}

Background: Structures that process sound and empower the brain to understand are called ears. This is the procedure in which analysis of sound signal is done through intensity and frequency.

Objective: To see the attitude of university students towards leisure noise-induced tinnitus and hearing loss.

Methodology: A cross-sectional study design was used having male and female university students exposed to leisure noise. "Youth Attitude Toward Noise Scale" (YANS) was used to see the knowledge of students about leisure noise-induced tinnitus and hearing loss. In this tool, there are 26 items comprising of 5 subscales. 15 items consist of perception of hearing loss, 7 items about using hearing protection and 4 about tinnitus. Data was collected from Bahaudin Zikria University, Lahore University of Management Sciences, University of Lahore and Riphah international university and evaluated on SPSS 19.

Results: Results of this study showed that $97.7 \%$ of students have middle attitude about knowledge of hearing loss and $48.6 \%$ said that tinnitus persists for less than 30 minutes after loud music exposure. $18.2 \%$ students agreed that they experience tinnitus after leisure activities. $38.7 \%$ students said that they don't use hearing protection because it puts too much pressure on ears.

Conclusion: The conclusion of this study showed that most of the youth were showing awareness about noise-induced hearing loss and tinnitus but they don't use hearing protection because of lack of knowledge of when to use hearing protection.

Keywords: Hearing Loss, Environmental noise.

\section{Introduction}

Ears are the structures that process sounds, empowering mental performance to understand what the patient is hearing. In other words, outer and middle ear receive and amplify sounds from the environment and convert these signals into electrical impulse which is directed towards brain. Pinna is the structure that conduits the sound waves into ear canal. Eardrum vibrates in response to these sound signals. These vibrations further transmit to the middle ear causing ossicles to vibrate, in response fluid in the cochlea and sensory cells vibrate. The biological changes to the ear are reproduced in an alteration in hearing sensitivity and or the development of tinnitus. ${ }^{1-3}$ Frequently hearing loss is bilateral, but it could be temporary or permanent. ${ }^{4}$ Attending discotheques, rock concerts and sporting events could cause temporary threshold shift. ${ }^{-9} 9$ If the person is continuously exposed to noise, hearing loss spreads to effect lower and higher frequencies and its generally in both ears and symmetrical. If an 
additional sound source is not present but someone is having impression of roaring, hissing or ringing sound in his ears it is called tinnitus. 10-13 Tinnitus can occur along with hearing loss or without hearing loss and it could be unilateral or bilateral. ${ }^{2}$ Temporary tinnitus can occur at recreational activities, such as discotheques, clubs, sporting events or music concerts. ${ }^{7}, 14-17$ Someone's quality of life is severely restricted due to communication handicap caused by hearing loss. ${ }^{18}$ Exposure of certainly damaging loud sounds in young adults is most common. Many studies shows that at dance clubs and rock concerts contact of music cause auditory difficulties. ${ }^{19-21}$ As electronic equipment and media is developing it causes damage to ears in young college students called noise induced deafness. ${ }^{22}$ Teenagers along with using their own stereo attend activities like discotheques and concerts which produce changes in organ of Corti. While $75-80 \%$ of teenagers in Mexico continue to expose themselves in noise although they know the secondary effect of noise exposure. ${ }^{23}$ Music at high-intensity levels can be viewed as continuous and unsteady sound which could induce transient temporary hearing loss with temporal manifestations that could last minutes, hours, or days following the termination of the intense stimulus, or which can be everlasting as a result of the repetitive experience of noise. ${ }^{24}$ The risk is higher in ears with the previous pathology. Regarding gender, women use direct protection barriers such as ear plugs and better environmental condition to protect their hearing. As the teenagers have longer contact duration with amplified music it increases the chance of hearing loss. ${ }^{25}$ The Medical Research Council has assessed that $>4000000$ adolescents suffer from hearing loss because of playing amplified music in Great Britain. In spite of the fact tinnitus after the loud music is a result of overexposure, adolescents do not at all times take tinnitus into justification as a notice sign. Consequently, many lack the motivation to wear HP in noisy environments. ${ }^{26}$ Also, most adolescents are thoughtless of hearing symptoms after loud music. In a study of Widen and Erlandsson, nearly $25.9 \%$ of youngsters suffering from tinnitus after the loud music started to be worried about noise levels in discotheques and at concerts. Contact to high sound levels during rest activities can cause irreversible hearing damage among young people. ${ }^{27}$ However, conflicting reports indicating that the utilization of PLDs had no damaging effects on the hearing of users have been published. The entire results of such studies show surprisingly low figures with regards to the current scientific ideas and even popular believes with this concern. In brief, other studies show alike and surprising results for a low incidence of noise-induced hearing loss between pop/rock musicians. On the other hand, noiseinduced hearing loss shows a significant prevalence among individuals exposed to industrial and other environmental noise.28-31 The rationale of this study was to know the knowledge of university students about leisure noise-induced hearing loss and tinnitus.

$$
\text { Methodology }
$$

Cross-sectional survey design was used for this study. Data was collected from Bahaudin Zikria University, Lahore University of Management Sciences, University of Lahore and Riphah international university. The study was completed within the duration of six months from July 2014 to December 2014. The sample size was calculated using online sample size calculator keeping the confidence level $95 \%$ confidence interval 5 and population infinity sample size was calculated 385.32 Convenient sampling technique was used for the study. All male and female university students exposed to leisure noise of $100-115 \mathrm{~dB}$ for the duration of 4hours, once in a month were included. To conduct the research, Youth Attitude toward Noise Scale (YANS) was used to know the knowledge of university students about leisure induced tinnitus and hearing loss that is a valid tool. ${ }^{33}$ 
Those who already have any kind of hearing loss were excluded. SPSS-19 was used for statistical analysis. Endnote was used for the purpose of referencing citations.

\section{Results}

From the sample of 385 participants, $57.14 \%$ were $18-20$ years. $40.26 \%$ were $21-23$ years and $2.60 \%$ were $24-26$ years old students. (Figure 1 )

$$
\begin{aligned}
& \text { 24-26yrs... } \\
& 21-23 y r s \\
& 40 \% \\
& 18-20 y r s \\
& 57 \% \\
& 18-20 y r s \quad \square 21-23 y r s ~ \\
& \hline
\end{aligned}
$$

\section{Figure No 1. Age Distribution of Study Participants}

In this study from the sample of $38552.2 \%$ students strongly agree, $28.8 \%$ students agree, $9.9 \%$ students were uncertain, $5.5 \%$ disagree and $3.6 \%$ students strongly disagree that the sound level at discos, dances, rock concerts and sporting events, in general, is too loud. Moreover, $68.8 \%$ students strongly agree, $21.6 \%$ agreed, $7.8 \%$ were uncertain, $1.0 \%$ disagreed and $0.8 \%$ strongly disagreed that it is important for them to make their sound environment more comfortable. $21.8 \%$ of total respondents strongly agreed, $28.3 \%$ agreed, $22.3 \%$ were uncertain about the response $17.9 \%$ disagreed and $9.6 \%$ strongly disagreed that they are prepared to give up activities where the sound is too loud. $24.9 \%$ students strongly disagree, $17.4 \%$ agree, 44.7 were uncertain, $8.1 \%$ disagree, $4.9 \%$ strongly disagree that they will use hearing protection in the future.(Table I)

This study shows that 184 females strongly agree, 75 agreed, 30 were uncertain, 12 disagreed, and 10 were strongly disagreed that there should be more rules or regulations for the sound levels in society but as compare to female results of male is that among 74 males 50 strongly agree, 10 were agree, 11 were uncertain, 2 disagree and 1 strongly disagreed that there should be more rules or regulations for the sound levels in society. (Table II)

This study shows that 184 females strongly agree, 75 agreed, 30 were uncertain, 12 disagreed, and 10 were strongly disagreed that there should be more rules or regulations for the sound levels in society but as compare to female results of male is that among 74 males 50 strongly agree, 10 were agree, 11 were uncertain, 2 disagree and 1 strongly disagreed that there should be more rules or

\begin{tabular}{|l|l|l|l|l|l|}
\hline Table I: Caption? & \multicolumn{3}{l}{$l$} \\
\hline Questions & $\begin{array}{l}\text { Strongly } \\
\text { agree }\end{array}$ & Agree & Uncertain & Disagree & $\begin{array}{l}\text { Strongly } \\
\text { disagree }\end{array}$ \\
\hline Level of sound at recreational activity places is too loud & $201(52.2)$ & $111(28.8)$ & $38(9.9)$ & $21(5.5)$ & $14(3.6)$ \\
\hline I consider leaving places where sound level is too loud & $81(21.0)$ & $100(26.0)$ & $76(19.7)$ & $69(17.9)$ & $59(15.3)$ \\
\hline $\begin{array}{l}\text { It's important to make sound environment more } \\
\text { comfortable }\end{array}$ & $265(68.8)$ & $83(21.6)$ & $30(7.8)$ & $4(1.0)$ & $3(0.8)$ \\
\hline $\begin{array}{l}\text { According to me it is unnecessary to use earplugs } \\
\text { where music is too loud }\end{array}$ & $155(40.3)$ & $82(21.3)$ & $77(20.0)$ & $42(10.9)$ & $29(7.5)$ \\
\hline At recreational places sound level should be low & $89(23.1)$ & $92(23.9)$ & $92(23.9)$ & $33(8.6)$ & $79(20.5)$ \\
\hline $\begin{array}{l}\text { I am ready to give up events where the sound level is } \\
\text { too loud }\end{array}$ & $84(21.8)$ & $109(28.3)$ & $86(22.3)$ & $69(17.9)$ & $37(9.6)$ \\
\hline Our society should maintain rules for sound levels & $234(60.8)$ & $85(22.1)$ & $41(10.6)$ & $14(3.6)$ & $11(2.9)$ \\
\hline I will do hearing protection in the future & $96(24.9)$ & $67(17.4)$ & $172(44.7)$ & $31(8.1)$ & $19(4.9)$ \\
\hline $\begin{array}{l}\text { Hearing protection reduces my ability to communicate } \\
\text { with others }\end{array}$ & $80(20.8)$ & $139(36.1)$ & $136(35.3)$ & $11(2.9)$ & $19(4.9)$ \\
\hline
\end{tabular}




\begin{tabular}{|c|c|c|c|c|c|c|c|}
\hline \multicolumn{8}{|c|}{ Table II: Cross tabulation of gender distribution about, Sound levels rules of society } \\
\hline & & \multicolumn{5}{|c|}{ There should be more rules or regulations for the sound levels in society } & \multirow[t]{2}{*}{ Total } \\
\hline & & $\begin{array}{l}\text { Strongly } \\
\text { agree }\end{array}$ & Agree & Uncertain & Disagree & $\begin{array}{l}\text { Strongly } \\
\text { disagree }\end{array}$ & \\
\hline \multirow{3}{*}{ Gender } & Male & 50 & 10 & 11 & 2 & 1 & 74 \\
\hline & Female & 184 & 75 & 30 & 12 & 10 & 311 \\
\hline & Total & 234 & 85 & 41 & 14 & 11 & 385 \\
\hline
\end{tabular}

In this study most of the students said that they experience mild tinnitus and least of them said that they experience unbearable tinnitus after at least 30 minutes of exposure to loud music.(Table III)

\begin{tabular}{|c|c|c|}
\hline \multicolumn{3}{|c|}{$\begin{array}{l}\text { Table III: Frequency distribution of severity of tinnitus } \\
\text { after } 30 \text { minutes loud music exposure }\end{array}$} \\
\hline Level of Tinnitus & Frequency & Percentage \\
\hline 0 & 51 & $13.2 \%$ \\
\hline 1 & 86 & $22.3 \%$ \\
\hline 2 & 128 & $33.2 \%$ \\
\hline 3 & 95 & $24.7 \%$ \\
\hline 4 & 15 & $3.9 \%$ \\
\hline 5 & 10 & $2.6 \%$ \\
\hline Total & 385 & $100.0 \%$ \\
\hline
\end{tabular}

Note: Point out below how loud the tinnitus is after at least 30 minutes of loud music exposure $(0=$ no tinnitus; $5=$ unbearable)

In this study $48.6 \%$ said that tinnitus persists for less than 30 minutes after loud music exposure, $15.1 \%$ said tinnitus persists between 30 minutes and 2 hours, 9.9\% said that tinnitus persists between 2 hours and 6 hours, $1.0 \%$ said that it persists for more than one day and $22.6 \%$ said that this point is not applicable.

\section{Discussion}

In the current study, students between the age of 18-23 years were most exposed to loud music. The previous study also shows that most of this age group is exposed to loud music. Today's leisure activities are modified that's why teenagers between age 16 and 25 years old are more exposed to loud music. ${ }^{10,34}$

The current study shows that women are more concerned about their hearing as compared to men they want to maintain better hearing levels in the society. The previous researches also showed better hearing environment as compared to men. Regarding gender, women use direct protection barriers such as ear plugs and better environmental condition to protect their hearing.

In the current study, most of the adolescents agreed that exposure to loud music can damage their hearing. $86.5 \%$ adolescents agreed that listening to music at high levels can damage their

hearing. In the previous study results showed that most of the adolescents hurt from listening to loud music. The Medical Research Council has assessed that $>4000000$ adolescents' effect from hearing loss due to listening to amplified music in Great Britain. Due to exposure of amplified sound and availability of personal stereos risk of hearing loss in teenagers is common.

The current study shows that $24.9 \%$ students strongly disagree, $17.4 \%$ agree, 44.7 were uncertain, $8.1 \%$ disagree, $4.9 \%$ strongly disagree that they will use hearing protection in the future. In the previous study, $24.7 \%$ of the students declared they would use HP in the future, whereas another $35.6 \%$ is considering doing so. It means more than half population are willing to protect their hearing as compare to $11 \%$ who actually use hearing protection.

\section{Conclusion}

Conclusion of this study showed that most of the youth agreed that noise levels are very high in our society like at discos, rock concerts and sporting events and they should be lowered. Students have knowledge that leisure noise can cause hearing loss and tinnitus, but they don't use hearing protection 
because of lack of knowledge when and where to use HP.

Recommendations: This study indicates that people are aware of the damage caused by PLD's and leisure noise, but a larger population study should be conducted to know the long term effects of leisure noise on hearing. There is also a need for manufacturers of PLD's to indicate the levels of PLD's that can cause hearing damage. Also, educational programs should be conducted in the society for the awareness of people to keep the volume low and use hearing protection. Acknowledgement: The coordinating services of my teacher Dr. Rashid Hafiz Nasir for their keen interest, useful suggestions together with the meaningful comments and cooperation deserve special mention here. My warm appreciation is cordially extended Dr. Nayab and Dr. Adnan for providing me with useful and informative materials.

\section{References}

1. Sliwinska-Kowalska M, Davis A. Noise-induced hearing loss. Noise and Health. 2012;14(61):274.

2. Fritschi L, Brown A, Kim R, Schwela D, Kephalopoulos S. Burden of disease form enviromental noise-Quantification of healthy life years lost in Europe. World Health Organization, Copenhagen, https://www who int/quantifying_ehimpacts/publications/e94888 pdf. 2011.

3. Hong $\mathrm{O}$, Kerr MJ, Poling GL, Dhar S. Understanding and preventing noise-induced hearing loss. Dis Mon. 2013;59(4):110-8.

4. Thorne P, Welch D, Grynevych A, John G, Ameratunga S, Stewart J, et al. Noise induced hearing loss: Epidemiology and noise exposure. Report for the Accident Compensation Commission and Department of Labour. 2011:129.

5. Harrison RV. Noise-induced hearing loss in children: A 'less than silent'environmental danger. Paediatrics \& child health. 2008;13(5):377-82.

6. Chung JH, Des Roches CM, Meunier J, Eavey RD. Evaluation of noise-induced hearing loss in young people using a web-based survey technique. Pediatrics. 2005;115(4):861-7.

7. Smith PA, Davis A, Ferguson M, Lutman ME. The prevalence and type of social noise exposure in young adults in England. Noise and health. 2000;2(6):41.

8. Holland III NV. Sound Pressure Levels Measured in a University Concert Band: A Risk of Noise-Induced Hearing Loss? Update: Applications of research in music education. 2008;27(1):3-8.

9. England B, Larsen JB. Noise levels among spectators at an intercollegiate sporting event. American journal of audiology. 2014;23(1).

10. Basner M, Babisch W, Davis A, Brink M, Clark C, Janssen $S$, et al. Auditory and non-auditory effects of noise on health. The lancet. 2014;383(9925):1325-32.
11. Langguth $B$, Kreuzer PM, Kleinjung $T$, De Ridder D. Tinnitus: causes and clinical management. The Lancet Neurology. 2013;12(9):920-30.

12. Mollasadeghi A, Mirmohammadi SJ, Mehrparvar AH, Davari MH, Shokouh P, Mostaghaci M, et al. Efficacy of low-level laser therapy in the management of tinnitus due to noise-induced hearing loss: a double-blind randomized clinical trial. The Scientific World Journal. 2013;2013.

13. Abraham Z, Massawe E, Ntunaguzi D, Kahinga A, Mawala $S$. Prevalence of Noise-Induced Hearing Loss among Textile Industry Workers in Dar es Salaam, Tanzania. Annals of global health. 2019;85(1).

14. Degeest S, Corthals P, Vinck BM, Keppler H. Prevalence and characteristics of tinnitus after leisure noise exposure in young adults. 2014.

15. Gilliver M, Beach EF, Williams W. Noise with attitude: Influences on young people's decisions to protect their hearing. International journal of audiology. 2013;52(sup1):S26-S32.

16. Bogoch II, House RA, Kudla I. Perceptions about hearing protection and noise-induced hearing loss of attendees of rock concerts. Canadian Journal of Public Health. 2005;96(1):69-72.

17. Bistrup ML, Keiding L. Children and noise-prevention of adverse effects. Copenhagen: National Institute of Public Health. 2002:17.

18. Tsakiropoulou E, Konstantinidis I, Vital I, Konstantinidou S, Kotsani A. Hearing aids: Quality of life and socio-economic aspects. Hippokratia. 2007;11(4):183.

19. Rawool VW, Colligon-Wayne LA. Auditory lifestyles and beliefs related to hearing loss among college students in the USA. Noise and Health. 2008;10(38):1.

20. Vogel I, Brug J, Van der Ploeg C, Raat H. Prevention of adolescents' music-induced hearing loss due to discotheque attendance: a Delphi study. Health education research. 2009;24(6):1043-50.

21. Folmer RL. Noise-induced hearing loss in young people. Pediatrics. 2006;117(1):248-9.

22. Kim MG, Hong SM, Shim HJ, Kim YD, Cha Cl, Yeo SG. Hearing threshold of Korean adolescents associated with the use of personal music players. Yonsei Medical Journal. 2009;50(6):771-6.

23. El Dib RP, Silva EM, Morais JF, Trevisani VF. Prevalence of high frequency hearing loss consistent with noise exposure among people working with sound systems and general population in Brazil: a cross-sectional study. BMC Public Health. 2008;8(1):1-8.

24. Niskar AS, Kieszak SM, Holmes AE, Esteban E, Rubin C, Brody DJ. Estimated prevalence of noise-induced hearing threshold shifts among children 6 to 19 years of age: the Third National Health and Nutrition Examination Survey, 1988-1994, United States. Pediatrics. 2001;108(1):40-3.

25. Clark WW. Noise exposure from leisure activities: a review. The Journal of the Acoustical Society of America. 1991;90(1):175-81.

26. Gilles A, De Ridder D, Van Hal G, Wouters K, Punte AK, Van de Heyning P. Prevalence of leisure noise-induced 
tinnitus and the attitude toward noise in university students. Otology \& Neurotology. 2012;33(6):899-906.

27. Serra MR, Biassoni EC, Richter U, Minoldo G, Franco G, Abraham $S$, et al. Recreational noise exposure and its effects on the hearing of adolescents. Part I: An interdisciplinary long-term study Exposición a ruido recreativo y sus efectos en la audición de los adolescentes. Parte I: un estudio interdisciplinario a largo plazo. International journal of audiology. 2005;44(2):65-73.

28. Corrêa Filho HR, Costa LS, Hoehne EL, Perez M, Nascimento L, de Moura EC. Noise-induced hearing loss and high blood pressure among city bus drivers. Revista de saude publica. 2002;36(6):693-701.

29. Hernandez-Gaytan S, Santos-Burgoa C, Becker-Meyer J, Macias-Carrillo C, Lopez-Cervantes M. Prevalence of hearing loss and correlated factors in a cement plant. Salud pública de México. 2000;42(2):106-11.

30. Miranda CR, Dias CR, Pena P, Nobre LC, Aquino R. Occupation deafness in industrialist workers of metropolitan region of Salvador, Bahia. Rev Bras Otorrinolaringol. 1998;64(2):109-14.

31. Wu T-N, Liou S-H, Shen C-Y, Hsu C-C, Chao S-L, Wang $\mathrm{J}-\mathrm{H}$, et al. Surveillance of noise-induced hearing loss in Taiwan, ROC: a report of the PRESS-NIHL results. Preventive medicine. 1998;27(1):65-9.

32. Online sample size calculator [English]. [Available from: https://www.calculator.net/sample-sizecalculator.html?type $=1 \& c l=95 \& c i=5 \& p p=50 \& p s=\& x=66 \& y=$ $\underline{19}$.

33. Meyer-Bisch C. Epidemiological evaluation of hearing damage related to strongly amplified music (personal cassette players, discotheques, rock concerts)-highdefinition audiometric survey on 1364 subjects. Audiology. 1996;35(3):121-42.

34. Gates GA, Schmid P, Kujawa SG, Nam B-h, D'Agostino R. Longitudinal threshold changes in older men with audiometric notches. Hearing research. 2000;141(12):220-8.

\section{Copyright Policy}

All Articles are made available under a Creative Commons "Attribution-NonCommercial 4.0 International" license. (https://creativecommons.org/licenses/by-nc/4.0/). Copyrights on any open access article published by Journal Riphah college of Rehabilitation Science (JRCRS) are retained by the author(s). Authors retain the rights of free downloading/unlimited e-print of full text and sharing/disseminating the article without any restriction, by any means; provided the article is correctly cited. JRCRS does not allow commercial use of the articles published. All articles published represent the view of the authors and do not reflect the official policy of IRCRC 